\title{
Amiodarone hydrochloride: enhancement of solubility and dissolution rate by solid dispersion technique
}

\author{
Alexandre Machado Rubim ${ }^{1 *}$, Jaqueline Bandeira Rubenick², Eduarda Gregolin², Luciane Varini \\ Laporta $^{1}$, Rosimar Leitenberg' ${ }^{2}$ Clarice Madalena Bueno Rolim ${ }^{1}$
}

\author{
${ }^{1}$ Department of Pharmacy, Federal University of Santa Maria, Santa Maria, RS, Brazil, ${ }^{2}$ Laboratory of Control of Drug \\ Quality, Franciscan University Center, Santa Maria, RS, Brazil
}

\begin{abstract}
Amiodarone $\mathrm{HCl}$ is an antiarrhythmic agent, which has low aqueous solubility and presents absorption problems. This study aimed to develop inclusion complexes containing hydrophilic carriers PEG 1500, 4000 and 6000 by fusion and kneading methods in order to evaluate the increase in solubility and dissolution rate of amiodarone $\mathrm{HCl}$. The solid dispersion and physical mixtures were characterized by X-ray diffraction, FT-IR spectra, water solubility and dissolution profiles. Both methods and carriers increased the solubility of drug, however PEG 6000 enhanced the drug solubility in solid dispersion better than other carriers. Different media were evaluated for the solubility study, including distilled water, acid buffer $\mathrm{pH} \mathrm{1.2,} \mathrm{acetate} \mathrm{buffer} \mathrm{pH} 4.5$ and phosphate buffer $\mathrm{pH} 6.8$ at $37^{\circ} \mathrm{C}$. Based on the evaluation of the results obtained in the study phase solubility carriers PEG 4000 and PEG 6000 were selected for the preparation of the physical mixture and solid dispersion. All formulations were prepared at drug-carrier ratios of 1:1 to $1: 10(\mathrm{w} / \mathrm{w})$. The results of in vitro release studies indicated that the solid dispersion technique by fusion method in proportion of $1: 10(\mathrm{w} / \mathrm{w})$ increased significantly the dissolution rate of the drug. X-ray diffraction studies showed reduced drug crystallinity in the solid dispersions. FT-IR demonstrated interactions between the drug and polymers.
\end{abstract}

Uniterms: Amiodarone hydrochloride/dissolution profile. Amiodarone hydrochloride/solid dispersion. Hydrophilic polymer.

Cloridrato de amiodarona é um agente antiarrítmico que possui baixa solubilidade aquosa e apresenta problemas de absorção. Este estudo teve como objetivo desenvolver complexos de inclusão contendo carreadores hidrofílicos PEG 1500, 4000 e 6000 através dos métodos de fusão e amassamento para avaliar o aumento da solubilidade e taxa de dissolução do cloridrato de amiodarona. As dispersões sólidas e misturas físicas foram caracterizadas por difração de raios-X, espectroscopia no infravermelho com transformada de Fourier, solubilidade em água e perfis de dissolução. Ambos os métodos e carreadores aumentaram a solubilidade do fármaco, no entanto o PEG 6000 aumentou a solubilidade do fármaco na dispersão sólida mais que os outros carreadores. Diferentes meios foram avaliados para o estudo de solubilidade, incluindo água destilada, tampão ácido $\mathrm{pH}$ 1,2, tampão acetato $\mathrm{pH}$ 4,5 e tampão fosfato pH 6,8. Com base na avaliação dos resultados obtidos no estudo de solubilidade de fases, os carreadores PEG 4000 e PEG 6000 foram selecionados para a preparação das misturas físicas e dispersões sólidas. Todas as formulações foram preparadas nas razões fármaco-carreador de 1:1 a 1:10 (p/p). Os resultados de liberação in vitro que a técnica de dispersão sólida pelo método de fusão na proporção 1:10 (p/p) aumentou significativamente a taxa de dissolução do fármaco. Estudos de difração de raios-X mostraram redução da cristalinidade do fármaco na dispersão sólida. Análise por espectroscopia no infravermelho mostrou interações entre o fármaco e o carreador.

Unitermos: Cloridrato de amiodarona/perfil de dissolução. Cloridrato de amiodarona/dispersão sólida. Polímero hidrofílico.

\footnotetext{
*Correspondence: A. M. Rubim. Laboratório de Controle de Qualidade de Fármacos. Departamento de Farmácia. Universidade Federal de Santa Maria. 97105-900 - Santa Maria - RS, Brazil. E-mail: alexandre.rubim01@gmail.com, clarice.rolim@gmail.com
} 


\section{INTRODUCTION}

Oral administration is the most common route for therapy of many diseases, however poorly soluble drugs have low bioavailability thereby decreasing treatment efficacy. For any active substance, aqueous solubility and intestinal permeability are key determinants that govern dissolution, absorption and oral bioavailability (Leuner, Dressman, 2000; Mutalik et al., 2008; Zisiou et al., 2005).

For certain drugs such as griseofulvin, indomethacin, chloramphenicol, carbamazepine, phenytoin, digoxin aqueous solubility is a challenge to researchers and the pharmaceutical industries (Badry, Fetih, Fathy, 2009; Meshal et al., 1993). Hence, different studies are performed to increase the rate of dissolution of poorly water soluble drugs, to increase their effectiveness and simultaneously reduce their doses hence their toxic effects (Patel et al., 2008).

Generally the techniques of chemistry modification, micronization, micellar solubilization, $\mathrm{pH}$ adjustment, use of solid dispersion, and formation of the inclusion compounds such as cyclodextrin and derivatives, are utilized for enhanced solubility of drugs (Alves et al., 2014; Chow et al., 1995; Flego, Lovrecich, Rubessa, 1988; Habib, Attia, 1985; Jablan, Szalontai, Jug, 2012; Vemula, Lagishetty, Lingala, 2010)

The solid dispersion technique was introduced in the early 1970s. Solid dispersion is one of the most successful strategies to improve the release of poorly soluble drug. This can be defined as dispersion of poorly water soluble drugs in hydrophilic carriers (Vasconcelos, Sarmento, Costa, 2007). The basic procedures used to prepare the solid dispersion are the fusion method, solvent evaporation method and hot extrusion method (Chiou, Riegelman, 1971; Modi, Tayade, 2006; Sammour et al., 2006). Drug solubility is improved based on three different mechanisms: the increased wettability of the drug, the reduction of particle size and increased surface area, and the conversion of the crystalline state to the more soluble amorphous state (Lloyd, Craig, Smith, 1999; Taylor, Zografi, 1997; Waard et al., 2008).

AMH, chemically known as (2-butylbenzofuran3-yl)[4-[2-(diethylamino)ethoxy]-3,5-diiodophenyl] methanone hydrochloride, is a benzofuranic derivate, used for the treatment of both supraventricular and ventricular arrhythmias. AMH is a white or almost white, crystalline powder and is very slightly soluble in water $(0.2-0.5 \mathrm{mg} / \mathrm{mL})$, freely soluble in methylene chloride, soluble in methanol, sparingly soluble in ethanol (96 per cent) (British Pharmacopoeia, 2012; Eghrary et al., 2012; Riekes, et al., 2010; Index Merck, 2001; US Pharmacopeia,
2012). AMH is classified as a class II drug based on the Biopharmaceutical Classification System (BCS), due to its low water solubility and high permeability (Riekes, et al., 2010).

Few studies were shown in the literature about the improvement of aqueous solubility and absorption of AMH including Elhasi, Astaneh, Lavasanifar(2007); Jouyban, Eghrary, Zarghami (2013); Martín-Algarra et al.(1995); Paduraru et al. (2013) and Riekes et al. (2010).

The present study aimed to develop inclusion complexes containing hydrophilic carriers in order to evaluate increased AMH solubility and dissolution rate. The physicochemical characteristics and dissolution were assessed using Fourier transform infrared, X-ray powder diffraction and in vitro dissolution profiles.

\section{MATERIAL AND METHODS}

\section{Material}

AMH with purity greater than $99.9 \%$ (standard substance) was obtained from Brazilian Pharmacopeia, batch 1040. The raw material AMH batch: 10104117A (purity $>99.0 \%$ ) was purchased from Pharmanostra ${ }^{\circledR}$ (Brazil). Polyethylene glycol 1500 (PEG 1500), 4000 (PEG 4000) e 6000 (PEG 6000) was purchased from Delaware ${ }^{\circledR}$ (Brazil). Water was prepared by ultra-pure water system (Milli- $\left.Q^{\circledR}\right)$. Other reagents and solvents used were of analytical grade.

\section{Methods}

\section{Determination of AMH content}

The AMH was quantified using the previously validated LC-method, employing a Shimadzu ${ }^{\circledR}$ (Kyoto, Japan), equipped with an LC-20AT pump, SIL-20A ht auto sampler, CTO-20AC column oven, SPD-M20A PDA detector, CBM-20A system controller, and LC solution software. The analyses were conducted using reverse phase Phenomenex ${ }^{\circledR}$ Luna $C_{18}$ column $(150 \mathrm{x}$ $4.6 \mathrm{~mm}, 5 \mu \mathrm{m})$. The mobile phase was composed of methanol:acetonitrile:buffer phosphate $\mathrm{pH} 2.2$ (68:15:17), with a flow rate of $1.0 \mathrm{~mL} \mathrm{~min}^{-1}$, at $25.0^{\circ} \mathrm{C}$ and a volume of $10 \mu \mathrm{L}$ was injected.

\section{Solubility studies}

This study was carried out to select a suitable dissolution medium for the in vitro drug release. An excess amount of AMH was transferred to an erlenmeyer, containing $10 \mathrm{~mL}$ of different solutions (distilled water, acid buffer $\mathrm{pH} 1.2$, acetate buffer $\mathrm{pH} 4.5$ and phosphate 
buffer $\mathrm{pH}$ 6.8). Flasks were covered to avoid solvent loss and then shaken at $120 \mathrm{rpm}$ in an orbital shaking incubator (Novatecnica $^{\circledR}, \mathrm{NT} 712$ ) for 24 hours at $37^{\circ} \mathrm{C} \pm 0.5^{\circ} \mathrm{C}$.

\section{Phase solubility study}

The phase solubility study was performed according to the method reported by Higuchi and Connors (1965). An excess amount of AMH was transferred to an Erlenmeyer flask containing $10 \mathrm{~mL}$ aqueous solutions with increasing concentrations of each carrier (i.e., 0.01, 0.05, 0.1, 0.3, $0.5,1.0$, and $1.5 \%)(\mathrm{w} / \mathrm{v})$. Flasks were covered to avoid solvent loss and then shaken at $120 \mathrm{rpm}$ in an orbital shaking incubator (Novatecnica ${ }^{\circledR}$, NT712) for 24 hours at 25 and $37^{\circ} \mathrm{C}$. After equilibrium, samples were centrifuged at $4000 \mathrm{rpm}$ for 15 minutes and filtered through a 0.45 $\mu \mathrm{m}$ membrane filter and analyzed for drug content using HPLC method. For determination of spontaneity of the dissolution process, the values of Gibbs free energy $\left(\Delta \mathrm{G}_{\mathrm{tr}}\right)$ were calculated for each carrier in different temperatures in accordance with equation 1 :

$$
\Delta G_{t r}=-2.303 R T \log \frac{S c}{S o}
$$

where: $R$ is the universal gases constant $\left(8.314472 \mathrm{~J} \mathrm{~K}^{-1} \mathrm{~mol}^{-1}\right), T$ is the temperature in Kelvin, $S c$ is the solubility of the drug at a certain concentration of the carrier and $S o$ is the concentration of AMH in water in the absence of carrier, both in $\mu \mathrm{g} / \mathrm{mL}$

\section{Preparation of solid dispersions and physical mixture}

For the preparation of the physical mixture and solid dispersions using different methods, initially the drug and carrier were sieved at $355 \mu \mathrm{m}$ mesh to standardize particle size and for storage in a desiccator.

\section{Physical mixtures (PM)}

The PM of drug with carrier was prepared by mixing proportions $1: 1$ and $1: 10(\mathrm{w} / \mathrm{w})$, respectively in a mortar for $10 \mathrm{~min}$.

\section{Solid dispersion by kneading method (SDKN)}

The SDKN of drug with carrier was started from the $\mathrm{PM}$, with subsequent kneading using water in a sufficient quantity to maintain a slightly moist consistency. After 20 min of kneading, the mixture was left at room temperature for 24 hours and the product obtained was powdered in a mortar and passed through a $335 \mu \mathrm{m}$ mesh.

\section{Solid dispersion by fusion method (SDFM)}

The SDFM of drug in carrier was prepared as follows. The drug was added to the molten carrier at
$80{ }^{\circ} \mathrm{C}$ with continuous stirring until the formation of a homogeneous dispersion. The dispersion was placed in a freezer at $-80{ }^{\circ} \mathrm{C}$ for 24 hours. After this period the product was ground using a mortar and passed through a $355 \mu \mathrm{m}$ mesh.

\section{Characterization of the solid dispersions}

\section{Fourier transform infrared spectroscopy (FT-IR)}

The samples were weighed about $5 \mathrm{mg}$ and they were homogenized with $300 \mathrm{mg}$ of potassium bromide using a mortar. The samples were then compressed using a hydraulic press to obtain a translucent tablet. The samples were scanned from (4000 to $450 \mathrm{~cm}^{-1}$ ) using a Perkin Elmer ${ }^{\circledR}$ spectrometer.

\section{$X$-ray powder diffraction analysis (XRD)}

The diffraction patterns of samples were obtained using an X-ray diffractometer (Rigaku ${ }^{\circledR}$, Miniflex300), using $\mathrm{Cu}$ as an anode material, operated at a voltage of $10 \mathrm{~mA}, 30 \mathrm{kV}$, monochromatic radiation $(\lambda=1.54051 \AA)$. The samples were analyzed from $5^{\circ}$ to $60^{\circ}$ in the range of $2 \theta$, in increments of $0.03 \%$.

\section{In vitro dissolution profiles}

Studies of dissolution of pure AMH, PMs and SDs with different carriers were performed in triplicate using dissolution test equipment, USP Apparatus 2 at $50 \mathrm{rpm}$ with $900 \mathrm{~mL}$ dissolution medium (i.e. water, hydrochloric acid $\mathrm{pH} 1.2$, buffer acetate $\mathrm{pH} 4.5$ and buffer phosphate 6.8 ) at $37{ }^{\circ} \mathrm{C} \pm 0.5^{\circ} \mathrm{C}$. Samples of pure drug, PMs and SDs equivalent to $100 \mathrm{mg}$ of the drug were utilized in evaluation. Dissolution studies were conducted for 90 minutes, and $10 \mathrm{~mL}$ were collected at 5, 10, 15, 30, 60 and 90 min intervals and replaced with an equal volume of fresh medium to maintain a constant total volume. The percentage of drug dissolved was determined using the HPLC method.

\section{RESULTS AND DISCUSSION}

\section{Solubility studies}

The effect of $\mathrm{pH}$ on AMH solubility was observed. This drug presented poorly solubility in $\mathrm{pH}$ similar to the intestine, whereas in more acidic $\mathrm{pH}$ the values were higher. The results found are shown in Table I.

After evaluation of this study it became clear that in media with a $\mathrm{pH}$ equal to or greater than $\mathrm{pKa}$ the drug ( 6.56 \pm 0.06 ) the molecule remains in a unionized form reducing the solubility (Boury et al., 2001; The Index Merck, 2001). 
TABLE I - Solubility values of AMH in different dissolution media at $37^{\circ} \mathrm{C} \pm 0.5^{\circ} \mathrm{C}$

\begin{tabular}{lc}
\hline Dissolution media & \% drug solubility \\
\hline Water distilled pH 5.5 & $14.20 \pm 0.5330$ \\
Acid buffer pH 1.2 & $0.1395 \pm 0.018$ \\
Acetate buffer pH 4.5 & $1.154 \pm 0.2152$ \\
Phosphate buffer pH 6.8 & $0.0409 \pm 0.0167$ \\
\hline
\end{tabular}

${ }^{\mathrm{a}}$ values are expressed as mean $\pm \mathrm{SD}, n=4$.

According to results, an increase of drug solubility in media with $\mathrm{pH}$ between 4.5 and 5.5 became clear. For this reason, these media were selected for evaluation of $\mathrm{AMH}$ solubility in solid dispersion. The high solubility of the drug in water when compared with the other media may be due to the presence of anions dissolved in buffer solutions, insoluble complexes being formed with molecules of the drug. (Avdeef, 2007; Boury et al., 2001; Ravin, Shami, Rattie, 1975).

\section{Phase solubility study}

The phase solubility curves of pure $\mathrm{AMH}$ in the presence of PEG 1500, 4000 and 6000 at 25 and $37^{\circ} \mathrm{C}$ are shown in Figure 1. The apparent solubility of AMH increased with increasing temperature and carrier concentrations. Using the highest carrier concentration, the aqueous solubility increased approximately 1.07, 1.31 and 5.72-fold for PEG 1500, 4000 and 6000, respectively at $25^{\circ} \mathrm{C}$ and $1.25,1.58$ and 3.51 -fold, respectively at $37^{\circ} \mathrm{C}$ compared to pure drug. The solubility found this study for $\mathrm{AMH}$ in water at 25 and $37^{\circ} \mathrm{C}$ was 0.2815 and 0.4808 $\mathrm{mg} / \mathrm{mL}$, respectively, very similar to that reported in the
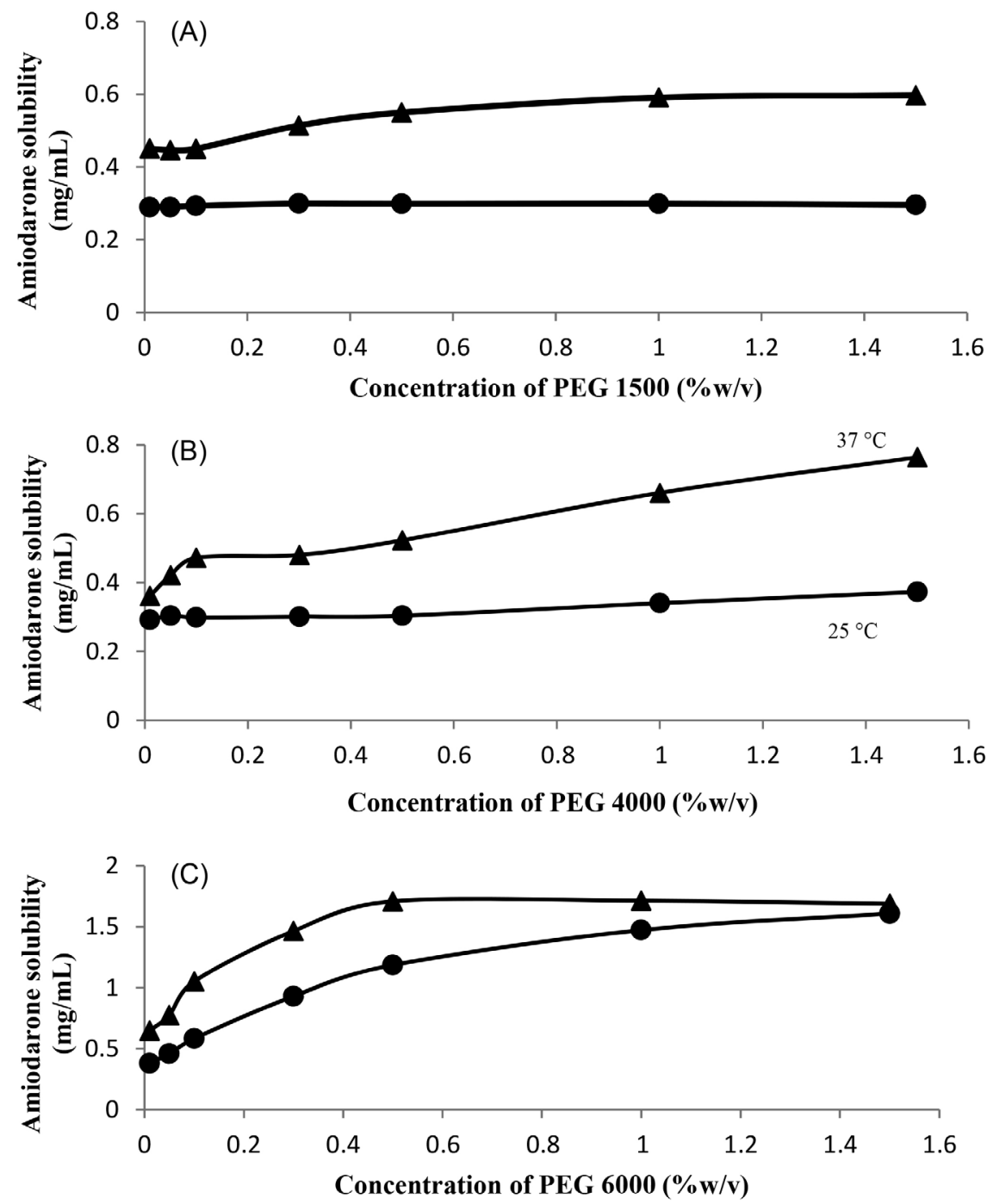

FIGURE 1 - Phase solubility curves of AMH in aqueous solutions of (A) PEG 1500, (B) PEG 4000 and (C) PEG 6000 at 25 and $37^{\circ} \mathrm{C} \pm 0.5^{\circ} \mathrm{C}(\mathrm{n}=3)$. 
literature (Amidon et al., 1995; Eghrary et al., 2012).

Table II shows the slopes of the curves. The higher slope value is associated with enhancement of the solubility. The Gibbs free energy $\left(\Delta \mathrm{G}_{\mathrm{tr}}\right)$ relating to the spontaneity of the process of drug dissolution in aqueous solutions containing different carriers is shown in Table II. Generally, the increase in solubility is directly associated with values of $\Delta \mathrm{G}_{\mathrm{tr}}<0$ being proportional to the increased carrier concentration (Patel et al., 2008).

In accordance with the results, the most negative values of $\Delta \mathrm{G}_{\mathrm{tr}}$ were found for carrier PEG 4000 and PEG 6000 in higher concentrations. After evaluation of the results obtained carriers PEG 4000 and PEG 6000 were selected for the preparation of the PMs and SDs. All formulations were prepared in the drug-carrier proportion of $1: 1$ and $1: 10(\mathrm{w} / \mathrm{w})$.

\section{Solid state characterization study}

\section{FT-IR spectroscopy studies}

Spectroscopy analysis was utilized for verification of nature of interactions between AMH and carrier PEG 6000. According to Verheyen et al. (2002), hydrogen bonding could be expected from the hydroxyl groups of PEG 6000. In the case of the AMH spectrum, the peaks in the region between 2960 and $2800 \mathrm{~cm}^{-1}$ are assigned to aliphatic $\mathrm{C}-\mathrm{H}$, the absorption bands characteristic to tert-amine $\mathrm{NH}^{+}$stretching are located in the 2700-2200 $\mathrm{cm}^{-1}$ range, at $1558 \mathrm{~cm}^{-1}$ and $1529 \mathrm{~cm}^{-1}$ related to aromatic $\mathrm{C}=\mathrm{C}$ ring stretching. The spectrum of pure $\mathrm{AMH}, \mathrm{PEG}$ 6000 and solid dispersions by fusion method are shown in Figure 2.

The intensity of peaks in 1477 and $1454 \mathrm{~cm}^{-1}$ for the aromatic $\mathrm{C}=\mathrm{C}$ ring semi-circle, at $1284 \mathrm{~cm}^{-1}$ specific to the ketonic $\mathrm{C}=\mathrm{O}$ binding, had a significant reduction in the spectrum of the solid dispersion by fusion method $1: 10(\mathrm{w} / \mathrm{w})$, moreover the bands between 2700-2200 $\mathrm{cm}^{-1}$ disappear from spectrum of solid dispersion. The FT-IR spectrum indicates that there is interaction between solid dispersion compounds and that it is likely that the complexation process was performed at the tert-amine of the AMH molecule.

TABLE II - Parameters for phase solubility studies of AMH obtained with different carriers at 25 and $37^{\circ} \mathrm{C} \pm 0.5^{\circ} \mathrm{C}$

\begin{tabular}{|c|c|c|c|c|c|c|}
\hline \multirow[b]{3}{*}{ Carrier } & \multicolumn{6}{|c|}{ Temperatures } \\
\hline & \multicolumn{3}{|c|}{$25^{\circ} \mathrm{C}$} & \multicolumn{3}{|c|}{$37^{\circ} \mathrm{C}$} \\
\hline & Slope & Solubility $^{\mathrm{a}}$ & $\Delta \mathrm{G}_{\mathrm{tr}}^{\mathrm{b}}$ & Slope & Solubility $^{\mathrm{a}}$ & $\Delta \mathrm{G}_{\mathrm{tr}}^{\mathrm{b}}$ \\
\hline PEG 1500 & 0.0041 & $0.3 \pm 0.006$ & -171.27 & 0.1102 & $0.6 \pm 0.006$ & -575.47 \\
\hline PEG 4000 & 0.051 & $0.37 \pm 0.004$ & -691.36 & 0.2449 & $0.76 \pm 0.004$ & -245.56 \\
\hline PEG 6000 & 0.8308 & $1.61 \pm 0.006$ & -4336.58 & 0.6434 & $1.69 \pm 0.021$ & -1185.38 \\
\hline
\end{tabular}

${ }^{a}$ Values of solubility in $1.5 \%(\mathrm{w} / \mathrm{v})$ of carrier concentration, in $\mathrm{mg} / \mathrm{mL} \pm \mathrm{SD}, n=2 ;{ }^{\mathrm{b}} \mathrm{Gibbs}$ energy free in $\mathrm{J} / \mathrm{mol}$.

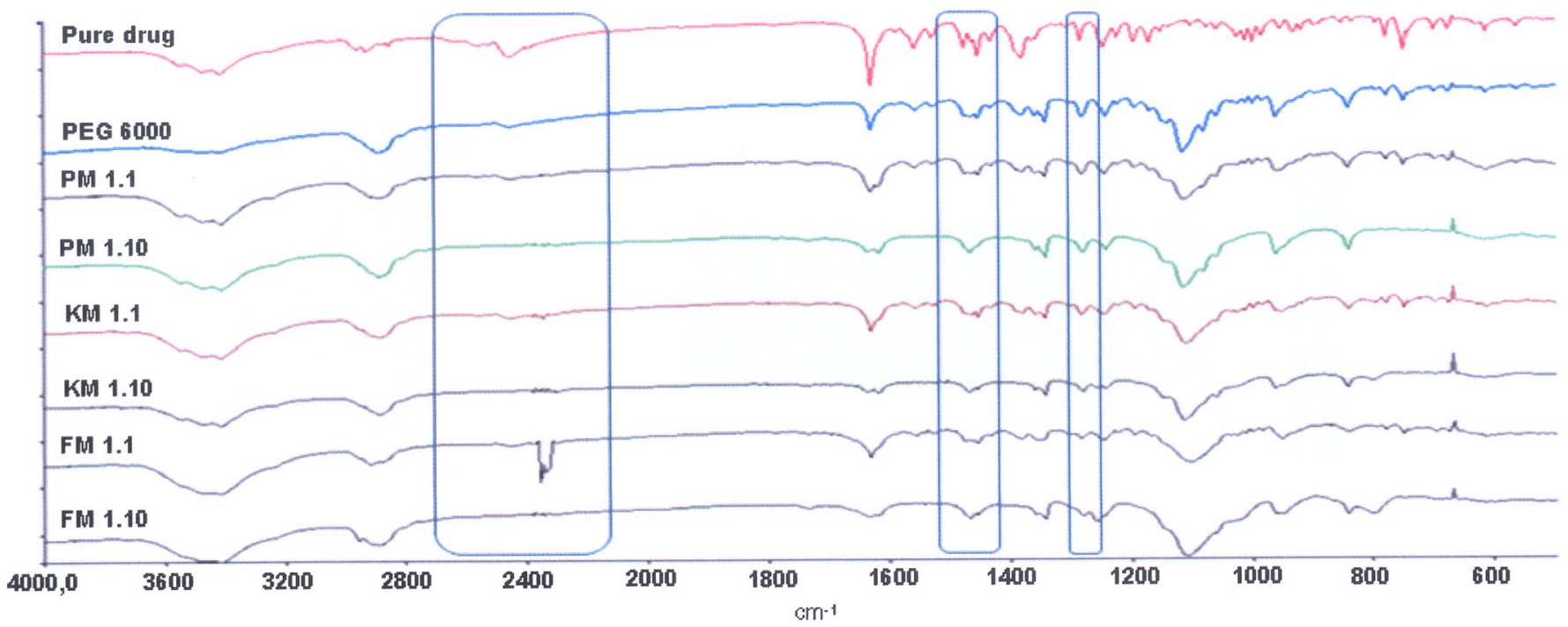

FIGURE 2 - FT-IR of the AMH pure (A), PEG 6000 (B), physical mixture, kneading method and fusion method. 


\section{XRD analysis}

The solubility, dissolution rate and bioavailability of some drugs can be parameters that depend on the solid-state form of the particles as amorphous, crystalline or polymorphic. The crystal is an organized structure in relation to molecules and atoms; on the other hand, the amorphous form is characterized by a random, generally more soluble state (Markovich et al., 1997).

The XRD pattern of pure drug, physical mixture and their solid dispersion using PEG 6000 as carrier are shown in Figure 3. The XRD pattern of pure AMH showed intense peaks of crystallinity and PEG 6000 exhibited distinct patterns with diffraction peaks. This characteristic was also observed in studies by Mandal et al. (2010) and Riekes et al. (2010), when the interaction between simvastatin and
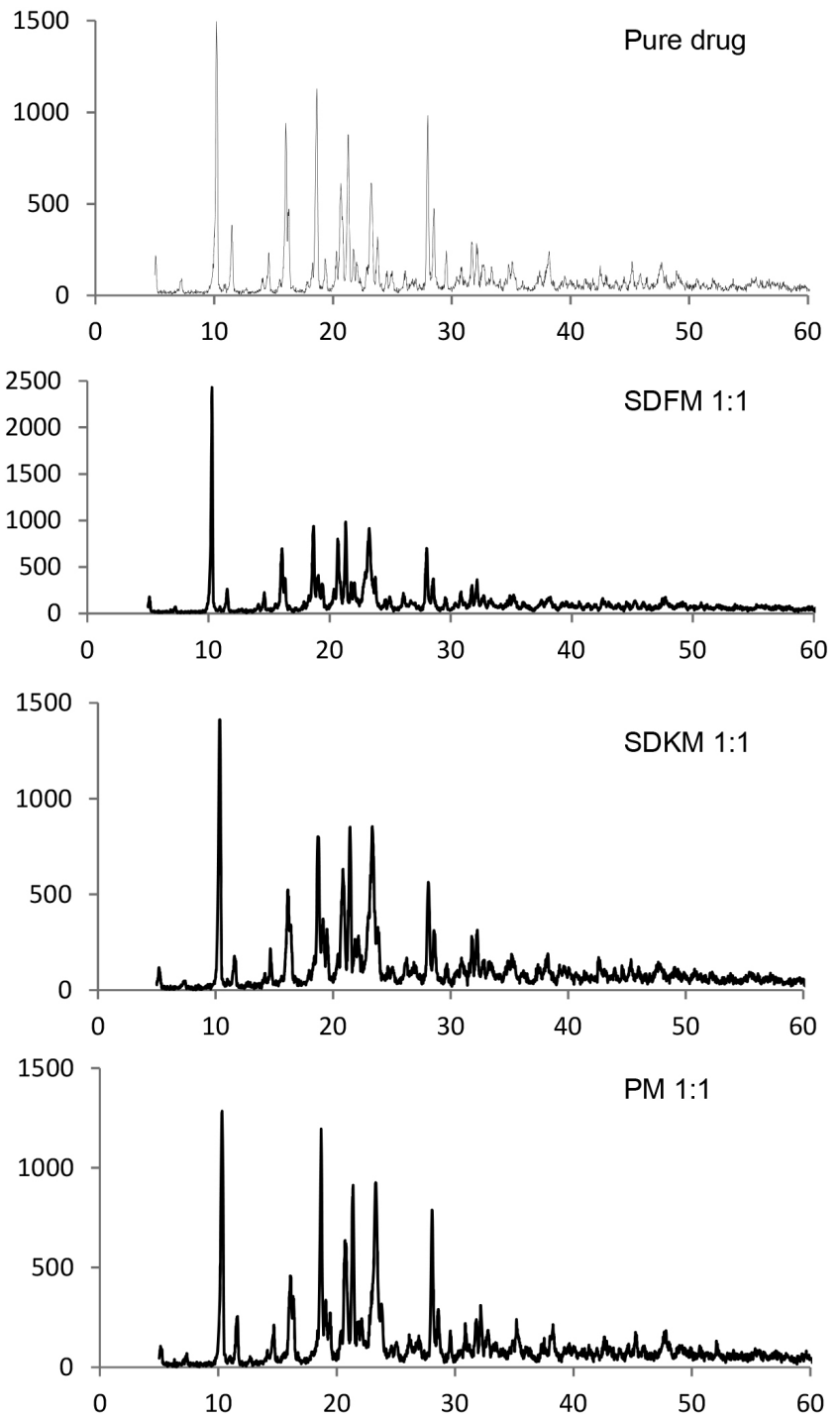

PEG 6000 and AMH and $\beta$-cyclodextrin, respectively, was evaluated.

PM and SDKM showed characteristic peaks of both drug and polymer indicating the presence of drug crystallinity in these samples. In solid dispersion by fusion method in a proportion of 1:10 (SDFM 1:10), the intensity of characteristic drug peaks decreased and some peaks were suppressed, thus indicating reduction of drug crystallinity.

\section{In vitro dissolution profiles}

For drugs with low gastrointestinal solubility and high permeability, in this case the $\mathrm{AMH}$, oral drug release is a limiting step for bioavailability. According to some authors, by improving drug solubility it is possible to
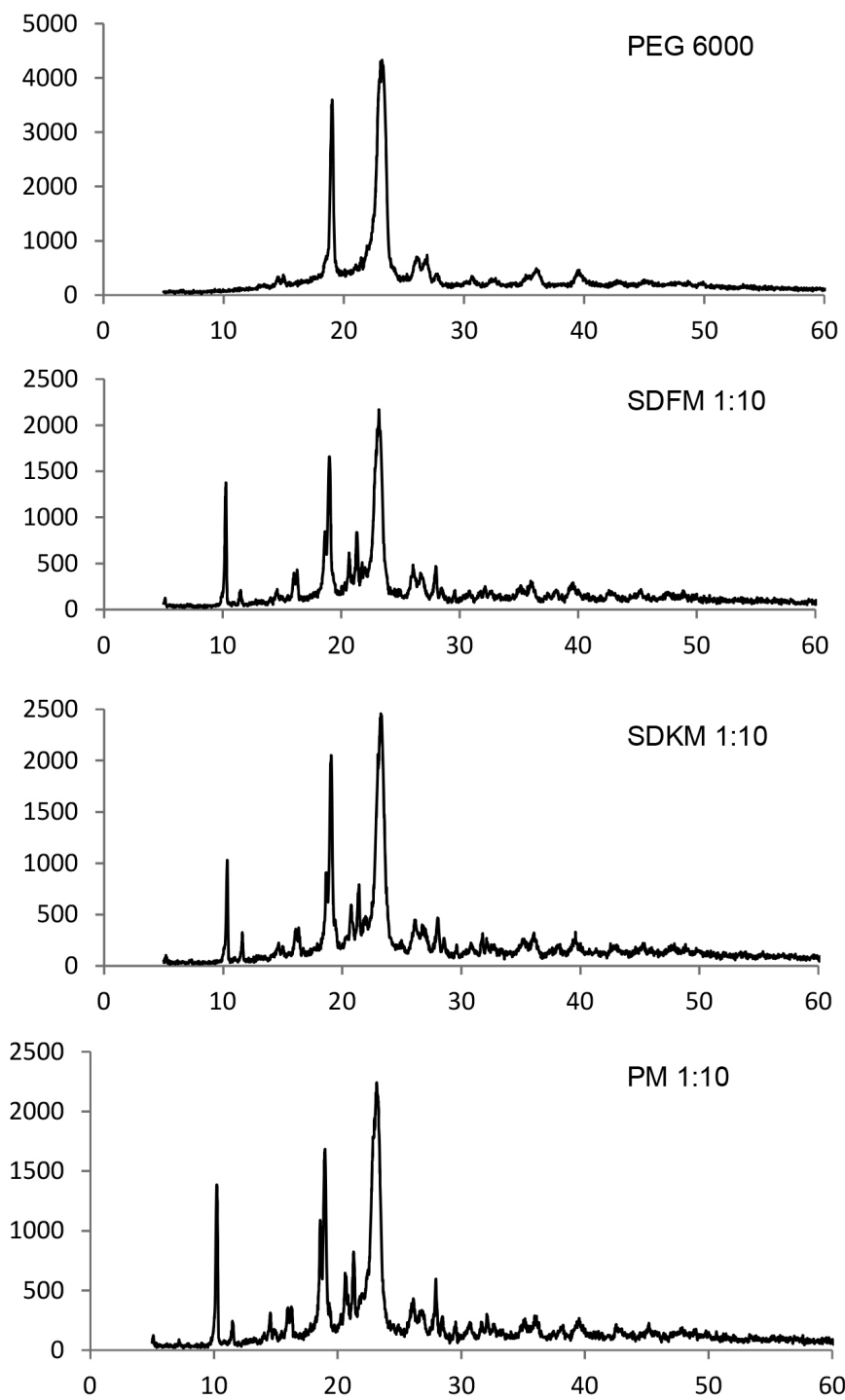

FIGURE 3 - X-ray diffraction patterns of AMH, physical mixture and solid dispersions. 
enhance their bioavailability and reduce side effects. This effect of increasing bioavailability is so great that the dose administered could be lowered (Leuner, Dressman, 2000; Streubel, Siepmann, Bodmeier, 2006; Vasconcelos, Sarmento, Costa, 2007). Poorly water-soluble drugs exhibit an insufficient dissolution rate and potential bioavailability problems due to erratic and incomplete absorption from the gastrointestinal tract (Bankar, Mahatma, 2012; Chiou, Riegelman, 1971).

The dissolution profiles of pure drug, physical mixture and solid dispersions in 1:1 and 1:10 ratios $(\mathrm{w} / \mathrm{w})$ using PEG 4000 and PEG 6000 in dissolution media such as water and acetate buffer $\mathrm{pH} 4.5$ are shown in Figure 4 and Figure 5, respectively.
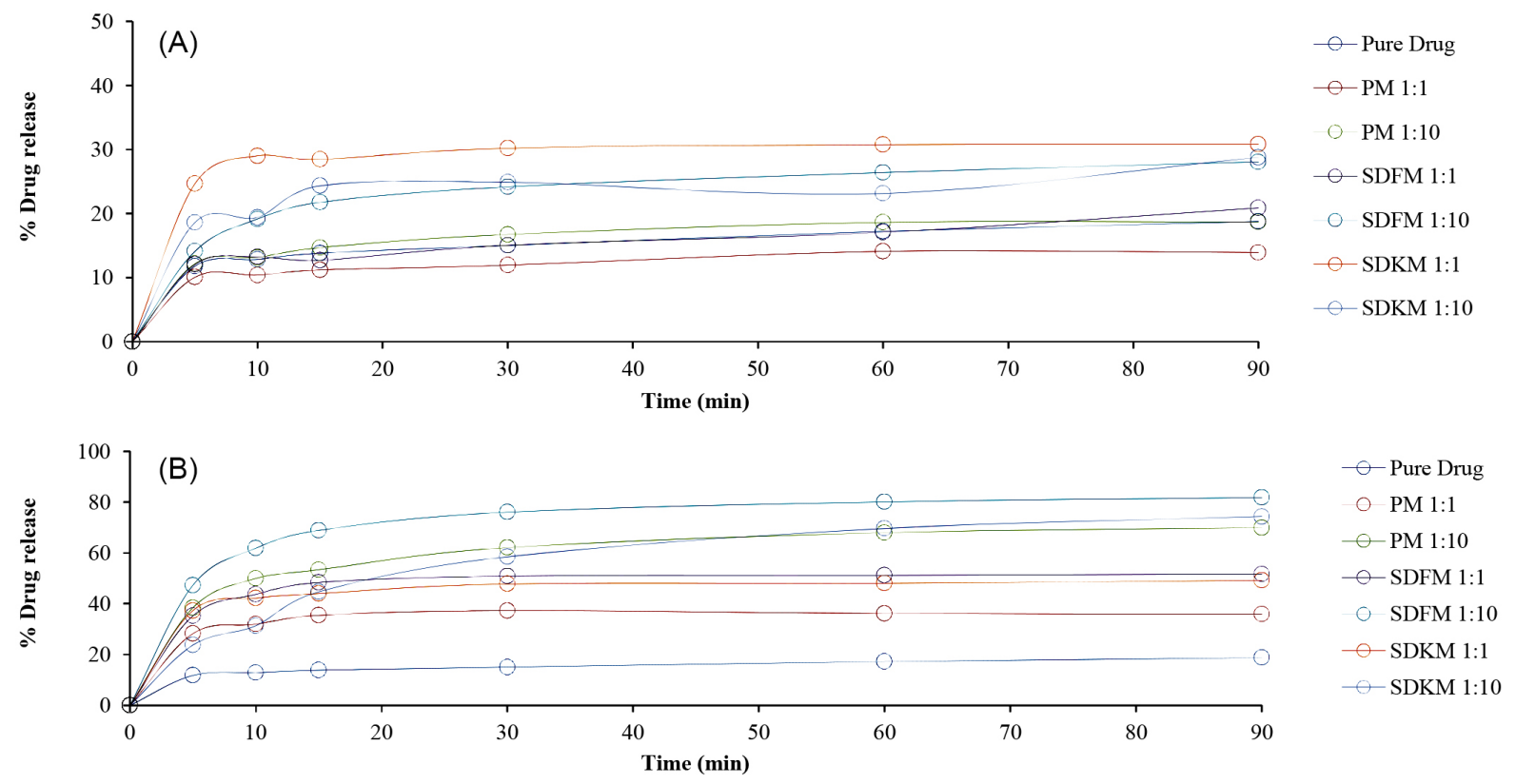

FIGURE 5 - Drug release profiles of pure AMH, physical mixture and solid dispersions obtained from fusion and kneading methods using acetate buffer $\mathrm{pH} 4.5$ as dissolution medium at $37^{\circ} \mathrm{C} \pm 0.5^{\circ} \mathrm{C}$ and carrier PEG 4000 (A) and carrier PEG 6000 (B).
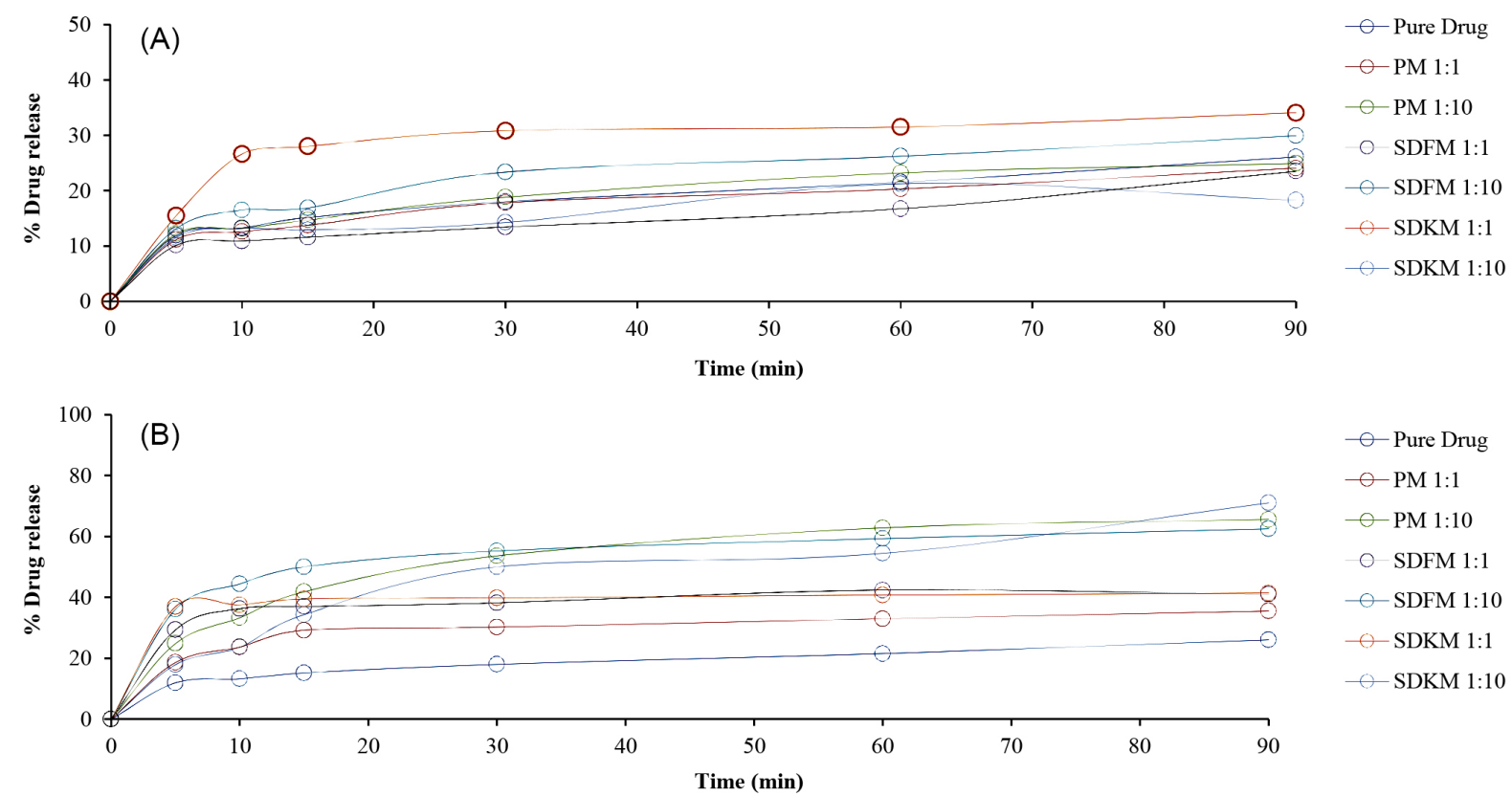

FIGURE 4 - Drug release profiles of pure AMH, physical mixture and solid dispersions obtained from fusion and kneading methods using water as dissolution medium at $37^{\circ} \mathrm{C} \pm 0.5^{\circ} \mathrm{C}$ and carrier PEG 4000 (A) and carrier PEG 6000 (B). 
Using PEG 4000 for preparation of formulations by the kneading method in the drug carrier proportion of $1: 1(\mathrm{w} / \mathrm{w})$, the highest values of dissolution rate of AMH were $0.038 \mathrm{mg} / \mathrm{mL}$ and $0.034 \mathrm{mg} / \mathrm{mL}$ in water and acetate buffer $\mathrm{pH} 4.5$, respectively. For preparation methods by fusion and physical mixture, the drug dissolution was similar for both media and proportions of drug-carrier evaluated.

On the other hand, using PEG 6000 as carrier, the dissolution rate of $\mathrm{AMH}$ was greater and faster for formulation prepared by the fusion method in a $1: 10$ $(\mathrm{w} / \mathrm{w})$ proportion of drug:carrier in both dissolution media. After evaluation of the dissolution rate between the media, the drug solubility was more relevant when acetate buffer $\mathrm{pH} 4.5$ was utilized as a dissolution medium. The product prepared by the fusion method at a proportion of $1: 10(\mathrm{w} / \mathrm{w})$ presented approximately a 4.4 fold increased solubility in acetate buffer 4.5 when compared with pure drug, demonstrating that it is an important tool for increasing the solubility of many molecules in biological fluids. With solid dispersion it became clear that drug solubility was increased compared with pure drug. This is explained by the formation of amorphous particles (as indicated by XRD analysis results), reduction of particle size and consequently larger surface area in contact with medium (Leuner, Dressman, 2000). Solid dispersions are one of the most successful strategies to improve solubility of drugs with low gastrointestinal solubility, where this promotes a greater quantity of drug molecules dissolved and free to be absorbed in the intestinal mucosa as in the case of AMH.

\section{CONCLUSION}

In this work, solid dispersions were prepared with AMH and PEG 1500, 4000 and 6000 with different weight rates and methods. In the solubility study, the AMH shows a good result in water and acetate buffer $\mathrm{pH} 4.5$ when compared with other media tested. The apparent solubility of AMH increased with increasing temperature and carrier concentrations and a more negative value of Gibbs free energy was obtained with carrier PEG 6000. FTIR and XDR studies showed evidence of interaction between the drug and PEG 6000 carrier for formulation SDFM 1:10 $(\mathrm{w} / \mathrm{w})$. Furthermore, this formulation showed significantly higher drug solubility compared with pure drug after in vitro dissolution studies. In conclusion, these results could be an indication that solid dispersion by the fusion method could be useful for the development of pharmaceutical products containing AMH.

\section{REFERENCES}

ALVES, L.D.S.; SOARES, M.F.R.; ALBUQUERQUE, C.T.; SILVA, E.R.; VIEIRA, A.C.C.; FONTES, D.A.F.; FIGUEIRÊDO, C.B.M.; SOBRINHO, J.L.S.; NETO, P.J.R. Solid dispersion of efavirens in PVP K-30 by conventional solvent and kneading methods. Carbohyd. Polym., v.104, p.166-174, 2014.

AMIDON, G.L.; LENNERNÃS, H.; SHAH, V.P.; CRISON, J.R. A theoretical basis for a biopharmaceutical drug classification: the correlation of in vitro drug product dissolution and in vivo bioavailability. Pharm. Res., v.12, n.3, p.413-420, 1995.

AVDEEF, A. Solubility of sparingly-soluble ionizable drugs. Adv. Drug. Deliv. Rev., v.59, n.7, p.568-590, 2007.

BADRY, M.; FETIH, G.; FATHY, M. Improvement of solubility of dissolution rate of indomethacin by solid dispersion in Gelucire 50/13 and PEG 4000. Saudi Pharm. J., v.17, n.3, p.217-225, 2009.

BANKAR, P.V.; MAHATMA, O.P. Improved dissolution rate of leflunomide using hydroxypropyl- $\beta$-cyclodextrin inclusion complexation by freeze-drying method. Int. J. Drug Deliv., v.4, n.4, p.498-506, 2012.

BOURY, F.; GAUTIER, J.; BOULIGAND, Y.; PROUST, J. Interfacial properties of amiodarone: the stabilizing effect of phosphate anions. Colloids. Surf. B., v.20, n.3, p.219227, 2001.

BRITISH PHARMACOPOEIA. London: The Stationary Office, 2012. v.1, p.137-138.

CHIOU, W.; RIEGELMAN, S. Pharmaceutical application of solid dispersion system. J. Pharm. Sci., v.60, n.9, p.12811302, 1971.

CHOW, A.; HSIA, C.; GORDON, J.; YOUNG, J.; BUTLER, E. Assessment of wettability and its relationship to the intrinsic dissolution rate of doped phenytoin crystals. Int. J. Pharm., v.126, n.1-2, p.21-28, 1995.

EGHRARY, S.H.;ZARGHAMI, R.; MARTINEZ, F.; JOUYBAN, A. Solubility of 2-butyl-3-benzofuranyl 4-(2-(diethylamino) ethoxy-3,5-diiodophenyl ketone hydrochloride (Amiodarone $\mathrm{HCl}$ ) in ethanol + water and $\mathrm{N}$-methyl-2pyrrolidone + water mixtures at various temperatures. J. Chem. Eng. Data., v.57, n.5, p.1544-1550, 2012. 
ELHASI, S.; ASTANEH, R.; LAVASANIFAR, A. Solubilization of an amphiphilic drug by poly(ethylene oxide)-blockpoly(ester) micelles. Eur. J. Pharm. Biopharm., v.65, n.3, p.406-413, 2007.

FLEGO, C.; LOVRECICH, M.; RUBESSA, F. Dissolution rate of griseofulvin from solid dispersion with poly(vinylmethylether:maleic anhydride). Drug Dev. Ind. Pharm., v.14, n.9, p.1185-1202, 1998.

HABIB, F.S.; ATTIA, M.A. Effect of particle size on the dissolution rate of monophenylbutazone solid dispersion in presence of certain additives. Drug Dev. Ind. Pharm., v.11, n.11, p.2009-2019, 1985.

HIGUCHI, T.; CONNORS, K. Phase-solubility techniques. Adv. Anal. Chem. Instrum., v.4, p.117-212, 1965.

JABLAN, J.; SZALONTAI, G.; JUG, M. Comparative analysis of zaleplon complexation with cyclodextrins and hydrophilic polymers in solution and in solid state. $J$. Pharm. Biomed. Anal., v.71, p.35-44, 2012.

JOUYBAN, A.; EGHRARY, S.H.; ZARGHAMI, R. Solubility of amiodarone $\mathrm{HCl}$ in propylene glycol + ethanol, propylene glycol + water and their ternary solvent mixtures at 25 and $37^{\circ}$ C. J. Mol. Liq., v.186, p.52-55, 2013.

KASIM, N.A.; WHITEHOUSE, M.; RAMACHANDRAN, C.; BERMEJO, M.; LENNERNÃS, H.; HUSSAIN, A.S.; JUNGINGER, H.E.; STAVCHANSKY, S.A.; MIDHA, K.K.; SHAH, V.; AMIDON, G.L. Molecular properties of Who essential drugs and provisional biopharmaceutical classification. Mol. Pharm., v.1, n.1, p.85-96, 2004.

LEUNER, C.; DRESSMAN, J. Improving drug solubility for oral delivery using solid dispersionss. Eur. J. Pharm. Biopharm., v.50, n.1, p.47-60, 2000.

LLOYD, G.R.; CRAIG, D.Q.M.; SMITH, A. A calorimetric investigation into the interaction between paracetamol and polyethylene glycol 4000 in physical mixes and solid dispersions. Eur. J. Pharm. Biopharm., v.48, n.1, p.59-65, 1999.

MANDAL, D.; OJHA, P.K.; NANDY, B.C.; GHOSH, L.K. Effect of carriers on solid dispersions of simvastatin (Sim): physico-chemical characterizations and dissolution studies. Der. Pharm. Lett., v.2, n.4, p.47-56, 2010.
MARKOVICH, R.J.; EVANS, C.A.; COSCOLLUELA, C.B.; ZIBAS, S.A.; ROSEN, J. Spectroscopic identification of an amorphous-to-crystalline drug transition in a solid dispersion SCH 48461 capsule formulation. J. Pharmaceut. Biomed., v.16, n.4, p.661-673, 1997.

MARTÍN-ALGARRA, R.; COSTA, R.; MERINO, M.; CASABÓ, V. Effects of polysorbate 80 on amiodarone intestinal absorption in the rat. Int. J. Pharm., v.122, n.1-2, p.1-8, 1995.

MESHAL, A.M.; MAHROOK, M.G.; ANGARY, A.A.; GOUDA, W.M. Interaction of carbamazepine with cyclodextrins. Pharm. Ind., v.55, n.12, p.1129-1132, 1993.

MODI, A.; TAYADE, P. Enhancement of dissolution profile by solid dispersion (kneading) techique. AAPS Pharm. Sci. Tech., v.7, n.3, p.1-6, 2006.

MUTAliK, S.; ANJU, P.; MANOJ, K.; USHA, A.N. Enhancement of dissolution rate and bioavailability of aceclofenac: a chitosan-based solvent change approach. Int. J. Pharm., v.350, n.1-2, p.279-290, 2008.

PADURARU, O.M.; BOSÎNCEANU, A.; TÂNTARU, G.; VASILE, C. Effect of hydroxypropryl- $\beta$-cyclodextrin on the solubility of an antiarrhythmic agent. Ind. Eng. Chem. Res., v.52, n.5, p.2174-2181, 2013.

PATEL, R.P.; PATEL, D.J.; BHIMANI, D.B.; PATEL, J.K. Physicochemical characterization and dissolution study of solid dispersions of furosemide with polyethylene glycol 6000 and polyvinylpyrrolidone K30. Dissolut. Technol., v.15, n.3, p.17-25, 2008.

RAVIN, L.J.; SHAMI, E.G.; RATTIE, E.S. Micelle formation and its relationship to solubility behavior of 2-butyl-3-benzofuranyl-4-(2-(diethylamino)ethoxy)3,5diiodophenylketone hydrochloride. J. Pharm. Sci., v.64, p.1830-1833, 1975.

RIEKES, M.K.; TAGLIARI, M.P.; GRANADA, A.; KUMINEK, G.; SILVA, M.A.S.; STULZER, H.K. Enhanced solubility and dissolution rate of amiodarone by complexation with $\beta$-cyclodextrin through different methods. Mater. Sci. Eng., v.30, p.1008-1013, 2010.

SAMMOUR, A.O.; HAMMAD, A.M.; MEGRAD, A.N.; ZIDAN, S.A. Formulation and optimization of mouth dissolve tablets containing rofecoxib solid dispersion. AAPS Pharm. Sci. Tech., v.7, n.2, p.167-175, 2006. 
STREUBEL, A.; SIEPMANN, J.; BODMEIER, R. Drug delivery to the upper small intestine window using gastroretentive technologies. Curr. Opin. Pharmacol, v.6, n.5, p.501-508, 2006.

TAYLOR, L.S.; ZOGRAFI, G. Spectroscopic characterization of interactions between PVP and indomethacin in amorphous molecular dispersions. Pharm. Res., v.14, n.12, p.1691-1698, 1997.

THE INDEX MERCK. 30.ed. Whitehouse Station: Merck Research Laboratories, Merck\&CO, INC. 2001. CD-ROM.

THE UNITED STATES PHARMACOPEIA. 35.ed. Rockville: United States Pharmacopeia convention, 2012. 2880 p.

VASCONCELOS, T.; SARMENTO, B.; COSTA, P. Solid dispersions as strategy to improve oral bioavailability of poor water soluble drugs. Drug. Discov. Today, v.12, n.23, p.1068-1075, 2007.
VEMULA, V.; LAGISHETTY, V.; LINGALA, S. Solubility enhancement techniques. Int. J. Pharm. Sci. Rev. Res., v.5, n.1, p.41-51, 2010.

VERHEYEN, S.; BLATON, N.; KINGET, R.; MOOTER, $\mathrm{V}$. Mechanism of increased dissolution of diazepam and temazepam from polyethylene glycol 6000 solid dispersion. Int. J. Pharm., v.249, n.1-2, p.45-58, 2002.

WAARD, H.; HINRICHS, W.L.J.; VISSER, M.R.; BOLOGNA, C.; FRIJLINK, H.W. Unexpected differences in dissolution behavior of tablets prepared from solid dispersions with a surfactant physically mixed or incorporated. Int. J. Pharm., v.349, n.1-2, p.66-73, 2008.

ZISIOU, E.P.; PINTO, P.C.A.G.; SARAIVA, M.C.M.F.S.; SIQUET, C.; LIMA, J.L.F.C. Sensitive sequential injection determination of naproxen based interaction with cyclodextrin. Talanta, v.68, n.2, p.226-230, 2005.

Received for publication on $15^{\text {th }}$ December 2014 Accepted for publication on $05^{\text {th }}$ August 2015 